\title{
Donorszelekciós kritériumok vizsgálata a debreceni veseátüiltetési programban
}

\author{
Zádori Gergely dr. - Tarjányi Vera - P. Szabó Réka dr. \\ Zsom Lajos dr. - Fedor Roland dr. - Kanyári Zsolt dr. \\ Kovács Dávid Ágoston dr. - Asztalos László dr. - Nemes Balázs dr.
}

Debreceni Egyetem, Általános Orvostudományi Kar, Sebészeti Intézet, Szervtranszplantációs Nem Önálló Tanszék, Debrecen

\begin{abstract}
Bevezetés: A donorszervhiány, a donorok életkorának növekedése és a társbetegségek gyakoribbá válása arra ösztönzi a transzplantálóközpontokat, hogy olyan donorvesék elfogadását is mérlegeljék, amelyeket korábban elutasítottak volna. A donorszelekciós kritériumok segíthetnek ennek eldöntésében. Célkitüzés: A különböző kritériumok hasznosságát illetően nincs egységes álláspont, ezért a szerzők megvizsgálták az expanded criteria donor, a deceased donor score és a kidney donor risk index donorszelekciós kritériumok hatását a posztoperatív vesefunkcióra és grafttúlélésre. Módszer: Ötéves intervallumban 205 donor paramétereinek és 138 veseátültetés kimenetelének retrospektív elemzését végezték el. Eredmények: Az expanded criteria donor rendszer szerint optimálisnak véleményezett donorok negyede a magas kockázatú csoportba került a deceased donor score alapján. A magas kockázatú csoportokban rosszabb volt a mütét utáni graftfunkció. A deceased donor score segítségével tovább lehetett bontani a magas kockázatú csoportot. Az így létrejött legmagasabb kockázatú csoport grafttúlélése és mútét utáni graftmúködése elmaradt a többi csoportéhoz képest. Következtetések: A vizsgált pontrendszerek segíthetnek a donorpool biztonságos növelésében. Orv. Hetil., 2016, 157(24), 946-955.
\end{abstract}

Kulcsszavak: veseátültetés, kiterjesztett donorkritériumok, kimenetel, marginális donor

\section{Analysis of donor scoring systems in a single Hungarian transplant centre}

Introduction: To ease organ shortage many transplant centres developed different donor scoring systems, however, a general consensus among clinicians on the use of these systems does not still exist. Aim: The aim of the authors was to analyse the effect of expanded criteria donor, deceased donor score and kidney donor risk index on postoperative kidney function and graft survival. Method: Analysis of the characteristics of 138 kidney transplantations and 205 donors in a retrospective study of a five-year period. Results: There was a trend towards rejecting donors in higher risk groups; $22.7 \%$ of standard criteria donors belonged to the high risk group of deceased donor score. Graft function was worse in high risk patients. High risk donors can be divided due to the use of deceased donor score. Patients with the highest risk had worse graft function and survival. Conclusions: With the use of these scoring systems grafts with favourable outcome can be selected more precisely.

Keywords: kidney transplantation, extended criteria donor, outcome, marginal donor

Zádori, G., Tarjányi, V., P. Szabó, R., Zsom, L., Fedor, R., Kanyári, Zs., Kovács, D. Á., Asztalos, L., Nemes, B. [Analysis of donor scoring systems in a single Hungarian transplant centreg]. Orv. Hetil., 2016, 157(24), 946-955.

(Beérkezett: 2016. április 10.; elfogadva: 2016. április 21.)

\section{Rövidítések}

$\mathrm{CIT}=($ cold ischemic time $)$ hideg ischaemiás idő; $\mathrm{CNI}=$ calcineurininhibitor; $\mathrm{DCD}=$ donation after cardial death; DDS = deceased donor score; DGF = delayed graft function; DSA = donorspecifikus antitest; $\mathrm{ECD}=$ expanded criteria donor; eGFR = számított glomerulusfiltrációs ráta; EPTS = estimated post-transplant survival; HCV $=$ hepatitis C-vírus; HLA = humán leukocyta-antigén; KDPI = kidney donor profile index; $\mathrm{KDRI}=$ kidney donor risk index ; OPTN = Organ Procurement and Transplantation Network; ROC = Receiver Operating Characteristic; SCD = standard criteria donor 
A szervátültetéseket megelőzően a donorok alkalmasságának elbírálása komplex folyamat, a döntés egyedi mérlegelést igényel. Mind a donor, mind a recipiens paramétereit figyelembe kell venni, és a kettő együtt határozza meg azt, hogy egy adott szerv beültethetö-e vagy sem. Az általános donorszervhiány arra ösztönzi a transzplantálóközpontokat, hogy az eddigi gyakorlatukhoz képest rugalmasabban kezeljék a donorszelekciós kritériumaikat és olyan szerveket is beültessenek, amelyeket korábban esetleg beültetésre alkalmatlannak ítéltek volna. Ennek célja, hogy a betegek várólistán eltöltött idejét lerövidítsük, ismert tény ugyanis, hogy a dialízisen eltöltött idő hossza negatívan befolyásolja a veseátültetés utáni grafttúlélést [1]. A korábban marginálisnak is nevezett, úgynevezett „expanded criteria donor”-okból (ECD) eltávolított szervek átültetésével szerzett tapasztalatok egyre széleskörúbbek. Azonban továbbra sincs egységes álláspont a donorok alkalmasságának elbírálásában, ezért több kritériumrendszert is kidolgoztak, és vizsgálták ezek használhatóságát a gyakorlatban. Az ECD fogalmát nemcsak veseátültetés, hanem például májátülttetés kapcsán is használják $[2,3]$.

Az ECD definíciója veseátültetés esetében az, ha a donor 60 évnél idősebb, illetve, ha a donor kora 50-59 év közötti és az alábbi három kritérium közül legalább kettő teljesül: donor anamnézisében szerepel hypertonia, az agyhalál oka valamilyen cerebrovascularis esemény volt, illetve, ha a donor szérumkreatinin-értéke (közvetlenül a szervkivétel előtt) nagyobb volt, mint $133 \mu \mathrm{mol} / 1$ (1,5 $\mathrm{mg} / \mathrm{dl}$ ). Ezeknek a feltételeknek a teljesülése esetén a graftelégtelenség rizikója a veseátültetést követően egy évvel másfélszerese az „optimális” donorból származó vese beültetéséhez képest [4]. Az ECD definíciója azonban elég tág, és emiatt a kiterjesztett donorcsoporton belül nem lehetséges a szervek további osztályozása. Felmerül, hogy a rosszabb vesetúlélést egy, az ECD-n belüli kisebb alcsoport okozza. Ha ez így van, akkor számos, egyébként jó eredménnyel beültethető donorveséről is lemondunk.

A 2003-ban közzétett DDS (deceased donor score) 5 paramétert vesz alapul, amelyek mindegyike befolyásolja a transzplantációt követôen 6 hónappal mért kreatininclearence-t [5]. Ezek: a donor életkora, az anamnézisében rögzített hypertensio, a donor számított kreatininclearence-e (csakúgy, mint az ECD esetén, ez is a terminális szérumkreatininen alapszik), a donor-recipiens HLA-egyezése, illetve a donor agyhalálának oka. Szemben az ECD-rendszerrel, a paraméterekhez egyenként pontokat rendel, és így négy csoportot határoz meg (grade A-D). Ez a beosztás csak a grade C és D esetén tekinti az adott donort ECD-nek.

2009-ben közölték a széles körben használt ECD-kritérium egy kibővített változatát, a kidney donor risk indexet (KDRI) [6], amelyet csaknem hetvenezer veseátültetés adataiból határoztak meg. Ebben a modellben a rizikó mértékét egy arányszám adja, amelyet 10 donorfaktorból számítanak ki: a donor életkora, magassága, testsúlya, etnikuma, hypertonia, diabetes jelenléte, az agyhalál oka, a szervkivételt megelőző utolsó mért szérumkreatinin, $\mathrm{HCV}$-státusz, végül a non-heart beating donor. A kritériumrendszernek van egy bővített változata is, amely a fentieken túl még a hideg ischaemiás időt (CIT) és a donor-recipiens HLA-egyezést is figyelembe veszi, kiegészítve azzal, hogy a recipiensbe csak az egyik vagy mindkét donorvesét ültették be. A referencia (azaz optimális) donor KDRI-értéke l-es, a paraméterei a következők: 40 éves agyhalott nem afroamerikai férfi (a KDRI az Egyesült Államokban végzett vizsgálaton alapul), aki HCV-negatív, anamnézisében nem szerepel sem hypertensio, sem diabetes, $170 \mathrm{~cm}$ magas és $80 \mathrm{~kg}$ testsúlyú, terminális szérumkreatinin-értéke 88,4 $\mu \mathrm{mol} / 1$, illetve az agyhalál nem valamilyen cerebrovascularis történés miatt következett be. A KDRI azt mondja meg, hogy mekkora a graftelégtelenség rizikója az adott vese beültetésével a referenciadonorhoz képest.

Végül említést érdemel a kidney donor profile index (KDPI). Ez az aktuális donor KDRI-értékének arányát adja meg az Organ Procurement and Transplantation Network adatbázisában szereplő donorok KDRI-értékeihez képest. A 80\%-os KDPI azt jelenti, hogy az aktuálisan jelentett donor KDRI-értéke magasabb az adatbázisban szereplő, a megelőző évben jelentett donorok 80\%-ánál. Mind a KDRI, mind a KDPI kiszámolható a United Network of Organ Sharing honlapján hozzáférhető szofver segítségével (http://optn.transplant.hrsa. gov/).

Egy korábbi közleményünkben vizsgáltuk az ECDgraftok hatását a veseátültetés eredményeire. Vizsgálatunk során nem találtunk különbséget a késôn meginduló vesemúködés, azaz delayed graft function (DGF) és akut rejectio előfordulási gyakoriságában $\mathrm{ECD}$, illetve az optimális vagy standard criteria donorból (SCD) származó vese átülttetése után, emellett nem találtunk különbséget a kumulatív beteg- és grafttúlélésben sem [7]. Jelen kutatásunk célja a fent említett három donorszelekciós kritérium (ECD, DDS, KDRI) hatásának vizsgálata a posztoperatív vesefunkcióra és grafttúlélésre.

\section{Betegek és módszer}

A 2011. január 1. és 2015. december 31. közötti időszak debreceni régiót érintő donációit és veseátültetéseket vizsgáltuk retrospektív módszerrel. A vizsgálatba csak a cadaver és primer transzplantációkat vontuk be, továbbá kizártuk a 18 évnél fiatalabb donorokat és recipienseket is. A fenti időszakban, a kizárási kritériumoknak is megfelelően, összesen 209 donorjelentés történt régiónkban, amelyekből 140 (67\%) esetben történt vesekivétel. A fennmaradó esetekben vagy már az elsődleges paraméterek feldolgozását követően elutasításra került a donor, vagy a donormútét megtörtént ugyan, de a helyszínen a szervkivételt végző team döntése alapján vesekivételre mégsem került sor. Az eltávolított 275 vese (5 esetben csak egy vese eltávolítása történt) közül 48-at (17\%) 
Debrecennek allokáltak, 190 (69\%) valamelyik másik szervátültető centrumban került beültetésre, végül 37 (14\%) vese nem került beültetésre. Az eltávolított, de beültetésre nem került vesék közül 25-öt a donor arteria renalis és a hozzá tartozó aorta patch súlyos arteriosclerosisa vagy a nem megfelelő perfúzió (nephrosclerosis) miatt utasított el a beültető team, a mütétet megelőző úgynevezett hidegpreparálás során. Tizenkét donor esetén csak az egyik vese került beültetésre, másik hazai centrumban. Ennek oka a veseparenchyma vagy a vesét ellátó erek sérülése, nagyméretű többszörös ciszták jelenléte vagy az egyik oldali vese arteria renalisának súlyos atherosclerosisa volt. A régiónkból származó és egyúttal klinikánk számára allokált 48 vesén túl még 105-öt ajánlottak fel intézetünknek más centrumból, ezekból 90 beültetésre került, így összesen 138 cadaver, primer transzplantációra került sor intézetünkben. A régiónkban jelentett donorok közül azokat, akiknek szerveit másik központ ültette át, kizártuk a további vizsgálatokból,

1. táblázat |Klinikánk részére felajánlott, de meghiúsult donációk okai

\begin{tabular}{ll}
\hline Visszautasítás oka & Esetszám $(\mathrm{N}=110 ; 100 \%)$ \\
\hline Proteinuria & $15(13,6 \%)$ \\
Családi tiltakozás & $14(12,7 \%)$ \\
Súlyos fokú arteriosclerosis & $13(11,8 \%)$ \\
(aortapatch vagy biopsziás minta lelete) & \\
Hepatitis B- vagy C-vírus-pozitivitás & $10(9,1 \%)$ \\
Beszúkült vesefunkció & $8(7,3 \%)$ \\
Donor igazolt extracerebralis tumora & $7(6,4 \%)$ \\
A donor legalább hármas & $7(6,4 \%)$ \\
kombinációban kap antihipertenzív & \\
gyógyszereket & \\
Idős donor & $6(5,5 \%)$ \\
Diabetes mellitus & $3(2,7 \%)$ \\
Szepszis & $3(2,7 \%)$ \\
Pozitív keresztpróba & $3(2,7 \%)$ \\
A graftban nagyméretú cisztát találtak & $2(1,8 \%)$ \\
Pyuria & $2(1,8 \%)$ \\
Haematuria & $2(1,8 \%)$ \\
Pyelonephritis & $2(1,8 \%)$ \\
Donor szívmegállása & $2(1,8 \%)$ \\
Sokk & $2(1,8 \%)$ \\
Masszív hypotensio, sokkvese & $2(1,8 \%)$ \\
A vesegraft foltosan perfundált & $1(0,9 \%)$ \\
Túl hosszú hideg ischaemiás idő & $1(0,9 \%)$ \\
MRSA-pozitivitás & $1(0,9 \%)$ \\
Donor-recipiens testtömeg jelentős & $1(0,9 \%)$ \\
eltérése & $1(0,9 \%)$ \\
Patkóvese & $1(0,9 \%)$ \\
Rheumatoid arthritis & $1(0,9 \%)$ \\
\hline Szisztémás lupus erythematosus &
\end{tabular}

így összesen 205 donorjelentés (debreceni régióból vagy másik centrumból osztályunknak felajánlott) adatait vizsgáltuk részletesen.

A klinikánk részére saját régiónkból vagy másik centrumból felajánlott, de meghiúsult donációk okai szerepelnek az 1. táblázatban. Leggyakoribb okok: proteinuria, családi tiltakozás, graft arteria renalis súlyos arteriosclerosisa. 20 esetben egynél több oka is volt a donor visszautasításának, leggyakrabban az időskor, hypertensio és proteinuria társult egymással. Az elutasított, illetve a transzplantációra alkalmas donorok adatait a 2. táblázat tartalmazza. A táblázatban nem szerepelnek azoknak a donoroknak a paraméterei, akiknek veséje családi tiltakozás vagy pozitív keresztpróba miatt nem került átültetésre. A korábban említett 138 primer veseátültetés 124 donorból történt, 14 donor esetén ugyanis a donor mindkét veséje a debreceni központban került beültetésre. A hazai gyakorlatban HCV-pozitív és nonheart beating (DCD) donor veséjének átültetésére nem

2. táblázat $\mid$ Az elutasított és a transzplantációra alkalmas donorok demográfiai adatai

\begin{tabular}{|c|c|c|c|}
\hline Demográfiai adatok & $\begin{array}{l}\text { Elutasított } \\
\text { donorok }(\mathrm{N}=81)\end{array}$ & $\begin{array}{l}\text { Transzplantációra } \\
\text { alkalmas donorok } \\
(\mathrm{N}=124)\end{array}$ & p-érték \\
\hline Nem (férfi/nő) & $\begin{array}{l}45 / 36 \\
(56 \% / 44 \%)\end{array}$ & $\begin{array}{l}71 / 53 \\
(57 \% / 43 \%)\end{array}$ & n. s. \\
\hline Kor (év) & $57 \pm 12$ & $51 \pm 12$ & $<0,001$ \\
\hline Testtömeg (kg) & $\begin{array}{l}80,6 \pm 17,6 \\
(N=69)\end{array}$ & $\begin{array}{l}78 \pm 16 \\
(\mathrm{~N}=114)\end{array}$ & n. s. \\
\hline Testmagasság $(\mathrm{cm})$ & $\begin{array}{l}171 \pm 10 \\
(N=69)\end{array}$ & $\begin{array}{l}171 \pm 9,4 \\
(\mathrm{~N}=114)\end{array}$ & n. s. \\
\hline Diabetes mellitus & $14 / 22 \%(\mathrm{~N}=64)$ & $9 / 10 \%(\mathrm{~N}=89)$ & 0,045 \\
\hline Hypertonia & $\begin{array}{l}59 / 79,7 \% \\
(\mathrm{~N}=74)\end{array}$ & $\begin{array}{l}53 / 52 \% \\
(\mathrm{~N}=101)\end{array}$ & 0,002 \\
\hline $\begin{array}{l}\text { Donor terminális } \\
\text { kreatinin }^{\mathrm{a}}(\mu \mathrm{mol} / \mathrm{l})\end{array}$ & $121,2 \pm 102,5$ & $81,9 \pm 35,2$ & $<0,001$ \\
\hline $\begin{array}{l}\text { Donoragyhalál } \\
\text { oka: } \\
\text { Cerebrovascularis/ } \\
\text { stroke } \\
\text { Trauma } \\
\text { Egyéb }\end{array}$ & $\begin{array}{l}67 / 82,7 \% \\
11 / 13,6 \% \\
3 / 3,7 \%\end{array}$ & $\begin{array}{l}87 / 70,1 \% \\
24 / 19,4 \% \\
13 / 10,5 \%\end{array}$ & n. s. \\
\hline ECD & $\begin{array}{l}56 / 71,8 \% \\
(\mathrm{~N}=78)\end{array}$ & $\begin{array}{l}46 / 39,7 \% \\
(\mathrm{~N}=116)\end{array}$ & $<0,001$ \\
\hline KDRI & $\begin{array}{l}1,44 \pm 0,39 \\
(\mathrm{~N}=69)\end{array}$ & $\begin{array}{l}1,19 \pm 0,34 \\
(\mathrm{~N}=114)\end{array}$ & $<0,001$ \\
\hline KDPI & $\begin{array}{l}76,93 \pm 20,82 \\
(\mathrm{~N}=69)\end{array}$ & $\begin{array}{l}61,97 \pm 25,06 \\
(\mathrm{~N}=114)\end{array}$ & $<0,001$ \\
\hline
\end{tabular}

A folytonos változókat átlagban és standard deviációban adtuk meg. Ahol az adatok hiányosak voltak, ott a mintaszámot külön feltüntettük. A különbséget akkor vettük szignifikánsnak, ha $\mathrm{p}<0,05$.

${ }^{a} A$ szervkivételt megelőző utolsó mért szérumkreatinin-érték.

$\mathrm{ECD}=$ expanded criteria donor; $\mathrm{KDPI}=$ kidney donor profile index; KDRI = kidney donor risk index. 
került sor. A recipiensek demográfiai adatait a 3. táblázat tartalmazza. Szintén ebben a táblázatban tüntettük fel a HLA-egyezéseket, a hideg ischaemiás időt, valamint a donorszelekciós kritériumok megoszlását is. Érdekesség, hogy a transzplantációra alkalmas donorok és a recipiensek átlagéletkora, testtömege és magassága gyakorlatilag megegyezett.

A donorszelekciós kritériumokat a korábban közölt tanulmányok alapján határoztuk meg [4-6]. Vizsgáltuk az egyes donorszelekciós kritériumokon belüli csoportok előfordulási gyakoriságát, illetve ezeknek a pontrendszereknek a hatását a posztoperatív 6. hónapban és első évben mért kreatininclearence-re, valamint a grafttúlélésre. A CIT, illetve a delayed graft function (DGF) definíciója megegyezett a korábbi közleményünkben leírtakkal [7]. A kreatininclearence számítása a DDS-pontozás során a Cockroft-Gault-képlet alapján történt, mert a DDS pontrendszere ezt használja, míg a posztoperatív vesefunkciót a CKD-EPI GFR-rel becsültük.

Emelkedett kockázat esetén a recipiensek indukciós kezelésben részesülnek. Emelkedett rizikónak tekintettük, ha a donor ECD volt, ha a CIT $<16$ óra és 2 egyéb immunológiai rizikófaktor jelen volt, ha a CIT 16-24 óra és legalább 1 immunológiai rizikófaktor jelen volt, illetve, ha a CIT>24 óra volt. Immunológiai rizikófaktoroknak tekintettük, ha a donor 50 évnél idősebb volt, ha a panelreaktív antigén (PRA) $>20 \%$, ha HLA-DR 1 mismatch állt fenn. Amennyiben a HLA-DR locusán 2 mismatch is szerepelt, ez 2 rizikófaktort jelentett. Az immunszuppresszió beállításakor Port és mtsai ECD-definícióját kiegészítettük a proteinuria mértékével is, feltéve, hogy erről volt pontos, kvantitatív adat. Ha az utóbbi nagyobb volt, mint $100 \mathrm{mg} / \mathrm{nap}$, ezt szintén egy kritériumnak vettük, és amennyiben a donor életkora 50-59 év között volt, a már korábban leírt három kritérium mellett ezt is figyelembe vettük. Indukciós kezelésként antithymocyta-globulint alkalmaztunk 1,5 mg/ttkg dózisban iv., a mútét napjától kezdve a posztoperatív 3-5. napig, de legalább két dózisban. A thymoglobulin-terápiát nem folytattuk a második dózis után, ha a szérumkreatinin ez idő alatt a mütét előtti érték 50\%-ára vagy $250 \mu \mathrm{mol} / 1$ alá csökkent, és/vagy korábban anuriás betegnél tartósan $100 \mathrm{ml} / \mathrm{h}$ diuresist észleltünk, illetve megszakítottuk, ha a thymoglobulin adásával kapcsolatos mellékhatást észleltünk. Az indukciós kezelést kezdetben iv., majd peroralis szteroid adásával egészítettük ki. A fenntartó peroralis szteroiddózis $5-10 \mathrm{mg}$ volt. Az immunszuppressziót mycophenolat mofetillel egészítettük ki az első posztoperatív naptól. Az ATG-kezelés befejezésével egy időben calcineurininhibitor (CNI) adagolását kezdtük. Amennyiben nem kaptak indukciós kezelést, úgy a CNI-t a mütét napjától kezdtük. A célgyógyszerszint - tacrolimus esetén - a veseátültetés utáni első két hétben 7-9 ng/ml volt indukció mellett, és 9-12 ng/ml, ha nem történt ATG-kezelés. A fentiek mellett a betegek antibiotikus, antifungális és pneumo- cystis pneumonia (PCP), valamint valganciclovir profilaxisban részesültek.

A statisztikai elemzéshez SPSS-t (SPSS, 22-es verzió, Inc., Chicago, Ill) használtunk. A szövegben a folytonos változókat átlagban és standard deviációban adtuk meg. A kategorikus változókat esetszámban és azok százalékos arányában adtuk meg. A folytonos változók elemzésekor Student t-próbát (többszörös összehasonlítás esetén ANOVA-tesztet Scheffe és Bonferroni posthoc tesztekkel), valamint Mann-Whitney-féle $U$-tesztet használtunk annak függvényében, hogy az adott változó normáleloszlást mutatott-e vagy sem. A kategorikus változók univariancia-vizsgálatát $\chi^{2}$-próbával, illetve Fischer-féle egzakt teszttel végeztük, a folytonos változók kapcsolatának vizsgálatához Pearson-korreláció-elemzést és lineáris regressziót alkalmaztunk. A változók graftvesztésre gyakorolt kumulatív hatását multivariancia-elemzéssel (Cox-regresszió) vizsgáltuk, majd ezt követően Receiver Operating Characteristic (ROC) -analízist végeztünk az eredmények szenzitivitásának és specificitásának meghatározására. A kumulatív grafttúlélést Kaplan-Meier- és log-rank analízissel vizsgáltuk. A különbségeket akkor tekintettük szignifikánsnak, ha $\mathrm{p}<0,05$ volt.

\section{Eredmények}

A beültetésre alkalmatlannak talált (úgynevezett elutasított) donorok életkora, a hypertonia és/vagy diabetes előfordulási gyakorisága, valamint terminális szérumkreatinin értéke szignifikánsan magasabb volt a transzplantációra alkalmas donorokéhoz képest (2. táblázat). A graftvesék beültetés előtt, steril körülmények között tört jégen végzett hideg preparálása (úgynevezett „backtable" perfúzió) során 48 esetben történt biopszia, miután kétségek merültek fel a beültethetőséget illetően. Ennek alapján három esetben döntöttünk úgy, hogy mégsem ültetjük be a vesét a biopsziás mintákban észlelt súlyos fokú arterioscleroticus elváltozások miatt. A fennmaradó esetekben az eltérések mértéke enyhébb volt. A patológus a legtöbb esetben ischaemiás tubularis károsodást $(82 \%)$ írt le, öt esetben minimális fokú glomerulosclerosist (ennek mértéke pontosan nem volt meghatározva), három biopsziás mintában csekély arteriola hyalinosist, enyhe interstitialis fibrosist négy mintában.

A transzplantációra alkalmas donorok között szignifikánsan alacsonyabb volt az ECD-k aránya, mint a visszautasított donorok között (39,7\% vs. 71,8\%, p<0,001) (2. táblázat). Más megfogalmazásban, az ECD-donorokból származó veséket gyakrabban utasítottuk vissza a standard criteria donorvesékhez képest ( $55 \%$ vs. $24 \%$, $\mathrm{p}<0,001)$. Az elutasított donorvesék esetében HLAegyezés hiányában utólag nem lehetett DDS-score-t számolni. Az elutasított donorok KDRI- és KDPI-értékei szignifikánsan magasabbak voltak a beültetésre alkalmasnak véleményezett donorok megfelelő értékeihez képest (KDRI: beültetésre alkalmas $1,19 \pm 0,34$; alkalmatlan $1,44 \pm 0,39 ; \mathrm{p}<0,001 ; \mathrm{KDPI}$ : beültetésre alkalmas 
$61,97 \pm 25,06$; alkalmatlan 76,93 $\pm 20,82 ; \mathrm{p}<0,001)(2$. táblázat). A recipiensek 42\%-a kapott ECD-donorból eltávolított vesét (3. táblázat). A beültetett vesék KDRIértéke átlagosan 1,21 volt. Ez azt jelenti, hogy a veseátültetést követően a graftelégtelenség kockázata 21\%-kal volt magasabb, mintha az OPTN adatbázisában szereplő referenciadonor veséjét ültettük volna át. A KDPI-értékek elemzése során pedig azt találtuk, hogy donoraink KDRI-értéke az előbbi adatbázisban szereplő donorok 63\%-ánál magasabb volt. A beültetett vesék átlagos DDS-pontszáma 20,1 volt (3. táblázat). A transzplantációra alkalmas donorok 79\%-a a DDS grade B-C csoportba tartozott.

3. táblázat $\mid$ A recipiensek demográfiai adatai és mútéttechnikai adatok

\begin{tabular}{lc}
\hline Demográfiai adatok & Recipiensek $(\mathrm{N}=138)$ \\
\hline Nem (férfi/nő) & $88 / 50$ \\
& $(64 \% / 36 \%)$ \\
Kor $($ év) & $51 \pm 12$ \\
Testtömeg $(\mathrm{kg})$ & $77,5 \pm 16,1$ \\
Testmagasság $(\mathrm{cm})$ & $170 \pm 8,9$ \\
Diabetes mellitus & $31 / 22,5 \%$ \\
Hypertonia & $105 / 76,1 \%$
\end{tabular}

Recipiens/donor között egyező

HLA-locusok száma $(\mathrm{N}=129)$

$\begin{array}{cc}0 & 1 / 0,8 \% \\ 1 & 8 / 6,2 \% \\ 2 & 43 / 33,3 \% \\ 3 & 35 / 27,1 \% \\ 4 & 28 / 21,7 \% \\ 5 & 8 / 6,2 \% \\ 6 & 6 / 4,7 \%\end{array}$

HLA-DR egyezés ( $\mathrm{N}=129)$

$\begin{array}{ll}0 & 20 / 15,5 \% \\ 1 & 60 / 46,5 \% \\ 2 & 49 / 38 \% \\ \text { Hideg ischaemiás idó (óra) }{ }^{\mathrm{a}} & 13,3 \pm 5,1 \\ \text { ECD } / \mathrm{SCD}(\mathrm{N}=130) & 54 / 76(41,5 \% / 58,5 \%) \\ \text { KDRI }(\mathrm{N}=121) & 1,21 \pm 0,34 \\ \text { KDPI }(\mathrm{N}=121) & 63,22 \pm 24,97 \\ \text { DDS-score }(\mathrm{N}=114) & 20,1 \pm 7,6 \\ \text { DDS grade }(\mathrm{N}=114) & \\ \text { A }(0-9 \text { pont }) & 13 / 11,4 \% \\ \text { B }(10-19 \text { pont }) & 38 / 33,3 \% \\ \text { C }(20-29 \text { pont }) & 52 / 45,7 \% \\ \text { D (30-39 pont }) & 11 / 9,6 \%\end{array}$

A folytonos változókat átlagban és standard deviációban adtuk meg. Ahol az adatok hiányosak voltak, ott a mintaszámot külön feltüntettük.

a A donoraorta lefogása és a veseátültetés során az érkirekesztók felengedése (declampage) között eltelt idő (óra).

DDS $=$ deceased donor score, $\mathrm{ECD}=$ expanded criteria donor; $\mathrm{KDPI}=$ kidney donor profile index; KDRI = kid $\neg$ ney donor risk index; $\mathrm{SCD}=$ standard criteria donor.
4. táblázat $\mid$ Az ECD/SCD, a DDS-, illetve a KDRI-csoportok összehasonlítása

\begin{tabular}{llll}
\hline $\begin{array}{l}\text { Donorszelekciós } \\
\text { kritériumok }\end{array}$ & SCD $(\mathrm{N}=66)$ & ECD $(\mathrm{N}=48)$ & p-érték \\
\hline DDS & $13 / 19,7 \%$ & 0 & \\
A & $38 / 57,6 \%$ & 0 & \\
B & $15 / 22,7 \%$ & $37 / 77,1 \%$ & \\
C & 0 & $11 / 22,9 \%$ & $<0,001$ \\
D & $1 \pm 0,2$ & $1,52 \pm 0,28$ & $<0,001$ \\
KDRI & $48,4 \pm 21,3$ & $84,5 \pm 10,4$ & $<0,001$ \\
KDPI & & & \\
\hline
\end{tabular}

DDS $=$ deceased donor score; $\mathrm{ECD}=$ expanded criteria donor; $\mathrm{KDPI}=$ kidney donor profile index; KDRI = kidney donor risk index; SCD = standard criteria donor

Összehasonlítva a különböző donorszelekciós kritériumok közötti átfedést, meglepő eredményekre jutottunk. Azt találtuk, hogy az ECD-csoportban nem fordult elő DDS A, illetve B csoportba sorolható donor, ugyanakkor az optimális donornak tartott SCD-k között 15-öt $(22,7 \%)$ a DDS grade C csoportba lehetett sorolni (4. táblázat).

Az ECD-csoporton belül a donorok 77\%-a a DDS grade $\mathrm{C}$, míg a fennmaradó esetek a $\mathrm{D}$ csoportba tartoztak. Az ECD-donorok KDRI- és KDPI-értéke is szignifikánsan magasabb volt az SCD-hez képest (4. táblázat).

Delayed graft function (DGF) 21 esetben (15\%) jelentkezett a mútéteket követően. Nem találtunk különbséget a DGF gyakoriságában a különböző csoportok között. A transzplantációt követő 6. hónapban és első évben mért eGFR-értékek magasabbak voltak az SCDcsoportban, mint az ECD-ben, a hat hónapos eltérés szignifikáns is volt (eGFR: $55,9 \mathrm{ml} /$ perc $/ 1,73 \mathrm{~m}^{2} \pm 21,4$ az SCD-csoportban és 45,3 $\pm 15,4$ az ECD-csoportban, $\mathrm{p}=0,005$; ugyanezen csoportokban az egyéves eGFRértékek $54 \pm 22,2$ és 48,6 $\pm 18,9, \mathrm{p}=\mathrm{NS}$ ). Ezzel összhangban, a DDS-kritériumrendszerben az egyre magasabb pontszámú csoportokban fokozatosan alacsonyabb eGFR-értékeket mértünk a posztoperatív 6 . hónapban. ANOVA-teszttel az A és B csoporthoz képest a D csoport eGFR-értékei szignifikánsan alacsonyabbak voltak (eGFR posztoperatív 6 . hónap A vs. $\mathrm{D}, \mathrm{p}=0,002 ; \mathrm{B}$ vs. $\mathrm{D}, \mathrm{p}=0,024)(1$ ábra). Egy évvel a veseátültetést követően, a DDS grade D csoportban továbbra is alacsonyabb az eGFR-érték, a különbség azonban már nem volt szignifikáns (1. ábra). Regressziós analízissel és Pearson-féle korrelációelemzéssel negatív korrelációt találtunk a donor KDRI-értéke és a posztoperatív 6. hónapban, valamint első évben mért eGFR-érték között $\left(\mathrm{R}^{2}=0,197, \mathrm{p}<0,001 ; \mathrm{r}=-0,444, \mathrm{p}<0,001\right.$, valamint $\left.\mathrm{R}^{2}=0,061, \mathrm{p}=0,039 ; \mathrm{r}=-0,247, \mathrm{p}=0,039\right)$.

A vizsgált ötéves periódusban a 138 veseátültetett betegből hárman $(2,1 \%)$ haltak meg megtartott graftmúködés mellett. Ezeknek a betegeknek a kiszúrésével kapjuk meg a „tiszta” (death-censored) grafttúlélést. Nem 

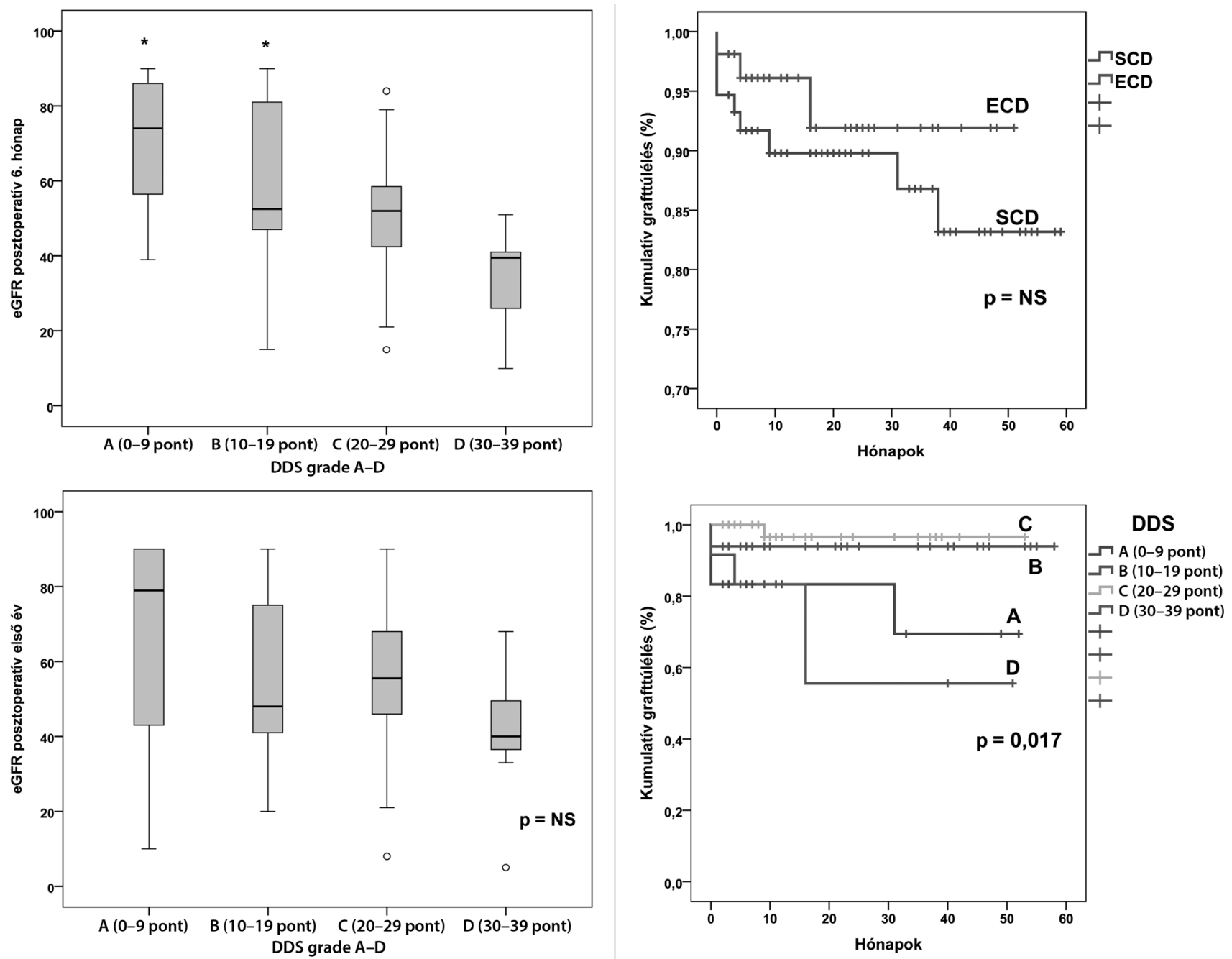

1. ábra

A veseátültetést követő 6 . hónapban és első évben mért eGFR-értékek a különbözó DDS-csoportokban

A *-gal jelölt csoportok eGFR-értékei szignifikánsan különböznek a grade D csoporthoz képest. $\mathrm{A}^{\circ}$-kal jelölt értékek kiugró értéket je-

lölnek. A különbséget akkor vettük szignifikánsnak, ha p $<0,05$

DDS $=$ deceased donor score $;$ eGFR $=$ számított GFR $($ CKD-EPI $)$

találtunk különbséget az ECD- és SCD-csoportok között, a veseátültetést követô 1 és 3 éves kumulatív grafttúlélésben, azonban a DDS grade D csoport túlélése szignifikánsan alacsonyabb volt a másik három DDS-csoportéhoz képest $(\mathrm{p}=0,017)$ (2. ábra). Multivarianciaanalízis (Cox-regresszió) során vizsgáltuk a donor hypertonia, diabetes, terminális szérumkreatinin, DDSpontszám, ECD/SCD státusz, KDRI és KDPI értékek hatását a graftvesztésre. A vizsgált változók közül a donornál a szervkivételt megelőzően mért utolsó kreatininérték, a KDRI és a KDPI szignifikáns összefüggést mutatott a graftvesztéssel (5. táblázat).

\section{Megbeszélés}

Vizsgálatunk során azt tapasztaltuk, hogy a beültetésre alkalmatlannak talált donorok között az ECD-k aránya

\begin{tabular}{l|l} 
2. ábra & $\begin{array}{l}1-3 \text { éves grafttúlélés az ECD } / \mathrm{SCD} \text {, illetve DDS-csoportokban } \\
\text { A különbséget akkor vettük szignifikánsnak, ha } \mathrm{p}<0,05 \\
\mathrm{DDS}=\text { deceased donor score; } \mathrm{ECD}=\text { expanded criteria donor; } \\
\mathrm{SCD}=\text { standard criteria donor }\end{array}$
\end{tabular}

magasabb volt, egyúttal ezek a donorok mind a DDS grade C és D csoportba sorolhatók voltak. Emellett a KDRI-értékeik is szignifikánsan magasabbak voltak a transzplantációra alkalmas donorokhoz képest (2. és 3. táblázat). Ez tehát, nem meglepően, megerősíti mind az ECD, DDS és KDRI hasznosságát a biztosan alkalmatlan donorok között.

Azonban az úgynevezett „szürke zóna” tekintetében az eredmények nem egyformák. A bizonytalan megítélésű donorok esetén egyes kritériumrendszerek differenciáltabb döntést tesznek lehetővé. Az ECD-klasszifikáció alapján optimálisnak (SCD) tartott donorok egynegyedét is a marginálisnak tekinthető DDS grade $\mathrm{C}$ csoportba lehetett sorolni. A DDS-score tehát a saját anyagunkon is alkalmas az ECD-donorok további csoportosítására, illetve, ahogyan arról már mások is beszámoltak, az igen tág kritériumokat alkalmazó ECD-scorerendszerrel „optimálisnak” tartott donorok is lehetnek marginálisak $[5,8]$. Ennek az a jelentősége, hogy a DDS 
5. táblázat $\mid$ Multivariancia-analízis (Cox-regresszió) az egyes változók és grafttúlélés kapcsolatának meghatározására

\begin{tabular}{lcll}
\hline Változók & $\operatorname{Exp}(\mathrm{B})$ & $95 \% \mathrm{CI}$ & $\mathrm{p}$ \\
\hline $\begin{array}{l}\text { Donor terminális } \\
\text { szérumkreatinin }\end{array}$ & 1,014 & $1,0-1,029$ & 0,05 \\
$(\mu \mathrm{mol} / \mathrm{l})$ & & & \\
KDRI & 176,982 & $3,54-8848,316$ & 0,01 \\
KDPI & 0,917 & $0,863-0,975$ & 0,005 \\
\hline
\end{tabular}

A grafttúlélés meghatározásakor azokat az eseteket, amikor a beteg exitált, de a graftmúködés még megtartott volt, kiszűrtük (death-censored grafttúlélés). A különbséget akkor vettük szignifikánsnak, ha $\mathrm{p}<0,05$.

${ }^{a}$ A szervkivételt megelőző utolsó mért szérumkreatinin-érték.

$\mathrm{KDPI}=$ kidney donor profile index; KDRI = kidney donor risk index

grade C és D csoport között különbséget mutattak ki a grafttúlélésben is, illetve a veseátültetést követően egy évvel mért recipiens eGFR értékben is. A DDS C csoport eredményei szignifikánsan jobbak, mint a DDS D csoportéi, azzal a kitétellel, ha a hideg ischaemia 12 óránál kevesebb volt [5]. Saját vizsgálatunkban a veseátültetést követő hatodik hónapban mért eGFR-értékek fordított arányban voltak a beültetett vese DDS-értékével (1. ábra). A DDS D csoportba sorolt donorok veséjének átültetése után az 1 és 3 éves grafttúlélés alacsonyabb volt a többi donorból származó vesék átültetése után észlelthez képest (2. ábra). Ezzel szemben az ECD-kritériumok alapján csoportosított donorok esetében nem találtunk különbséget a grafttúlélésben, viszont a veseátültetés után hat hónappal mért eGFR-értékek ebben a pontrendszerben is az ECD-csoportban voltak alacsonyabbak. Úgy gondoljuk, hogy a DDS előnye az ECDklasszifikációval szemben az, hogy segítségével kiválaszthatók a graftok közül azok (DDS-C), amelyek átültetésével az eredmények még nem romlanak az „optimális" graftokhoz képest. Hátránya ugyanakkor a DDS-score-nak, hogy a GFR-t a Cockroft-Gault-formula szerint számítja, ami a jelenleg használt EPI-GFR-rel szemben nem veszi alapul a beteg testfelületét és így pontatlanabb a kreatininclearence becslésére [9]. A donorok KDRI-értéke szintén jól korrelált a posztoperatív 6. hónapban mért eGFR-rel, amely megegyezik az irodalomban leírtakkal [6]. Egy másik hazai munkacsoport is vizsgálta marginális vesék átültetését követően a graftfunkció változását, és úgy találták, hogy a veseátültetést követően egy évvel nem volt különbség a számított GFR-értékekben a két csoport között, viszont öt évvel a transzplantációt követően már igen, marginális vese átültetését követően alacsonyabb volt. Ebben a vizsgálatban a marginális donorkritériumok a következők voltak: ha a donoréletkor $>55$ év, ha non-heart beating donorból történt a szervkivétel, ha a CIT>36 óra és ha a donor legalább 10 éve diabetesben vagy hypertoniában szenved [10]. A DDS-hez hasonlóan a KDRI-rendszernek is vannak limitáló tényezői. Nem veszi figyelembe a graft esetleges sérülését, anatómiai abnormalitásait, a donorrecipiens életkor- és méretbeli különbözőségeit, az alapbetegség kiújulásának rizikóját, a veseátültetés előtti donorspecifikus antitestek (DSA) jelenlétét.

Az Egyesült Államokban 2014 végére a KDRI-KDPI használata széles körben elterjedt a szervek allokációjával kapcsolatban. Meghatározzák a recipiens EPTS (estimated posttransplant survival - veseátültetés utáni várható túlélés) értékét. Ezt négy összetevőből számítják: dialízisen töltött idő, a recipiens életkora, diabetes jelenléte, megelőző szervátültetés (https://optn.transplant.hrsa. gov/ContentDocuments/Guide_to_Calculating_Interpreting_EPTS.pdf). A várható túlélés annál nagyobb, minél kisebb az EPTS értéke. A leírt gyakorlat szerint alacsony EPTS-értékű recipienseknek alacsony KDPI-értékű veséket allokálnak és fordítva, minél alacsonyabb egy beteg várható túlélése a transzplantáció után, annál „marginálisabb” vesét allokálnak a számára. Tekintettel arra, hogy a KDPI egyik legfontosabb összetevője a donor életkora, ez az allokációs gyakorlat összhangban van az Eurotransplant Senior Programjával, amely során a 65 évnél idősebb donorok veséjét 65 évnél idősebb, nem immunizált ( $\mathrm{PRA}<5 \%$ ) recipienseknek ajánlják fel, előzetesen nem figyelembe véve a HLA-egyezést [11, 12], előnyben részesítve az alacsony CIT-időt. Az idősebb vesék ugyanis érzékenyebbek az ischaemiás-reperfúziós károsodásra, ennek következtében gyakrabban lép fel delayed graft function, ami a vesetúlélést is negatívan befolyásolja [13, 14]. Az ET Senior Program eddigi eredményeit megerősíti az a tény, hogy ebben a csoportban a 3 éves grafttúlélés (a beteg halála miatti graftvesztés kizárásával) nem különbözött a hagyományos HLA-egyezésen alapuló allokációs rendszerben észlelttől [15].

Az UNOS és az ET Senior Programjának allokációs gyakorlatát számos tanulmány támasztja alá. Több tízezer beteg vizsgálata során azt találták, hogy a vesetranszplantáció utáni várható túlélés magasabb a dialízisen maradt betegekéhez képest [16], és ez 70 [17], sőt 75 évnél idősebb recipiensek esetén [18], valamint marginális vesék transzplantációja után is igazolható [19]. Utóbbi tanulmányban úgy találták, hogy marginális vesék átültetése után a 65 évnél idősebb betegek várható élettartama átlagosan 3,8 évvel volt hosszabb a dialízisen maradt hasonló életkorú betegekéhez képest. Ebben a vizsgálatban a marginális donor kritériumai a következők voltak: 55 évnél idősebb donoréletkor, több mint 10 éve fennálló hypertensio és/vagy diabetes, non-heart beating donor, CIT>36 óra.

Egy tanulmányban több mint 1200 veseátültetett beteg adatait felhasználva vizsgálták a recipiens-donor életkor hatását a grafttúlélésre. 55 évnél fiatalabb és idősebb recipienseket, illetve donorokat hasonlítottak össze négy csoportban (fiatal-fiatal, fiatal-idős, idős-fiatal, idős-idős) és úgy találták, hogy amennyiben 55 évnél fiatalabb recipiensekbe ültettek 55 évnél idősebb veséket, a grafttúlélés szignifikánsan rosszabb volt a többi csoportéhoz képest [20]. 
A már részletezett és vizsgált kritériumokon túl számos másik ismert még az irodalomban. Schold és mtsai 2005-ben közöltek egy score-rendszert, amely a DDSen alapszik [21]. További rizikófaktorként számításba vették még a donor CMV-pozitivitását, etnikumát, a diabetest és a CIT hosszát. A donorokat grade I-V csoportokba sorolták. Úgy találták, hogy a magasabb pontszámú csoportokban szignifikánsan rosszabb volt a grafttúlélés, illetve gyakoribb volt a DGF és akut rejectio előfordulása az alacsonyabb pontszámú csoportokéhoz képest.

Segíthet a donorvese transzplantációra való alkalmasságának elbírálásában a veseátültetést megelőzően vett graftbiopszia is. Ezt tipikusan ECD-nek tartott veséknél alkalmazzák. Az Egyesült Államokban a marginális vesék 75\%-ából biopsziát vesznek, ugyanakkor nem találtak összefüggést az ECD-vesékben leírt glomerulosclerosis és a későbbi graftmúködés között [22]. Anyagunkban a beültetésre kerülő vesék közül (138) 48 esetben végeztünk nullbiopsziát, amelyek többségében enyhe fokú eltéréseket írtak le. A vese elutasítása három esetben történt a szövettani lelet alapján. A transzplantáció előtti graftbiopszia hasznosságát több szerző is megkérdőjelezi, ennek ellenére nagyon sok esetben a biopsziát követően kerül sor egy vese elutasítására [23]. A transzplantáció előtti kreatininclearence sokkal jobban korrelált a posztoperatív graftfunkcióval, mint a mútétet megelőző biopszia során meghatározott glomerulosclerosis mértéke [24].

Több szerző nem pusztán a glomerulosclerosist, hanem több elváltozást is vizsgált a bioptátumokban. Karpinski és mtsai 34 donor vesebiopsziás mintáit vizsgálták az alábbi szempontok alapján: glomerulosclerosis, interstitialis fibrosis, tubularis atrophia és vascularis eltérések [25]. Ezen a vizsgálaton alapszik a Remuzzi (Pirani) -score is, amely a szövettani eltéréseket pontozva három fó csoportba sorolja a veséket aszerint, hogy mennyi életképes nefron található bennük [26]. A pontrendszer alapján 0-3 pontig elegendő mennyiségű nefron van a graftban a szoliter átültetéshez, 4-6 pont között a donor mindkét veséjének egyazon recipiensbe ültetése javasolt, 7 pont fölött pedig egyáltalán nem javasolt a vese beültetése. Utóbbi multicentrikus, randomizált, prospektív vizsgálatban azt találták, hogy amennyiben a biopszia eredményétől függően végezték el 60 évnél idősebb donorból a veseátültetést (szoliter vagy kettő vese transzplantációja), szignifikánsan jobb volt a grafttúlélés azokhoz a betegekhez képest, akik előzetes biopszia nélkül kaptak 60 évnél idősebb donorvesét. (Ezekben az esetekben mindig egy vese átültetése történt.) A vizsgálat során két prediktív faktort is megállapítottak a hosszú távú graftfunkcióra: a donor életkorát és a preoperatív biopsziás leletet. A Karpinski-és Remuzzi-vizsgálatoknak azonban vannak korlátai: vascularis laesiók nem egységes definíciói, nem lehetséges a vizsgálatok közötti összehasonlítás, alacsony a betegszám, az eredmények nincsenek független kohorszvizsgálatokkal alátámasztva, nem túl hosszú a követési idő (Remuzzi munkacsoportja által publikált tanulmányban a medián utánkövetés 23 hónap volt), emellett multivariancia-analízissel nem zárták ki a klinikai paraméterek (például donoréletkor) egyidejü lehetséges hatását a graftfunkcióra.

$\mathrm{Az}$ Anglicheau-score a klinikai paramétereket (donorkreatinin és hypertensio), illetve a biopsziás mintában észlelt glomerulosclerosis mértékét is figyelembe veszi [27]. Ez a score-rendszer korrelált a posztoperatív első évben mért kreatininclearence-szel, illetve a grafttúléléssel. Gandolfini és szerzôtársai [28] is javasolják marginális donoroknál a graftbiopszia elvégzését, az ő anyagukban 80 feletti KDPI-score esetén, és javasolják ennek eredményét figyelembe venni a vesegraft elfogadásánál. Vizsgálatuk során akkor vettek biopsziát a graftból, ha a donor 65 évnél idősebb volt, ha az MDRD alapján számított kreatininclearence értéke kevesebb volt, mint $60 \mathrm{ml} /$ min, illetve, ha a proteinuria mértéke nagyobb volt napi 1 g-nál. A biopsziák kiértékelésénél a Remuzzi-pontrendszert vették alapul. Csakúgy, mint a Remuzzi-munkacsoport, amennyiben a biopszia pontszáma 4 alatt volt, szoliter veseátültetést, 4-6 közötti pontszám esetén mindkét donorvese átültetését végezték. A szerzők azonban megjegyzik, hogy mindkét vese átültetése nagyobb mútéti rizikóval jár, mint a szoliter veseátültetés.

A fenti tanulmányok kapcsán már említett hátrányokon túl továbbiak is szerepelnek, amelyek megkérdőjelezik a veseátültetés előtt vett biopszia valós hasznosíthatóságát. Az egyik probléma az, hogy a biopszia kiértékelése sok esetben szubjektív és függ a vizsgálótól. A glomerulosclerosis mértékének megítélése nagymértékben függ a biopsziában megtalálható glomerulusok számától, valamint attól, hogy a biopszia során a vesekéreg capsula fibrosához közeli rétegéből vagy mélyebbről történt a mintavétel [29, 30]. A vizsgálat pontossága függ a minta fixálásától is. Fagyasztott vizsgálattal csak korlátozottan értékelhető a mesangialis sejtdússág, diabeteses elváltozások, microthrombusok, illetve akut tubularis necrosis [31]. A formalinban fixált, paraffinba ágyazott metszetek elkészítése azonban időigényes, akár 4-5 órával is megnyújtják a hideg ischaemiás időt, amire viszont az ECD-vesék kifejezetten érzékenyek. Az egyik centrumban lecsökkentették a veseátültetést megelőző biopsziák arányát $85 \%$-ról 24\%-ra, ezzel párhuzamosan a hideg ischaemiás idő is jelentősen csökkent. Ennek következtében a DGF arányának csökkenését tapasztalták [32]. További hátrány, hogy szövettani elemzés a legtöbb helyen csak munkaidőben végezhető.

\section{Következtetések}

Nincs egységes nemzetközi konszenzus a cadaver donorok szervátültetésre való alkalmasságának elbírálásában, számos donorszelekciós kritériumrendszert alkalmaznak a különböző központok. A donor-recipiens szelekcióban segíthetnek ezek a pontrendszerek, amelyek segítségével a marginális veséket is több csoportba lehet sorolni 
és így pontosabban meg lehet határozni azt a betegkört, amelyik a legtöbbet nyer egy ilyen vese átültetésével.

A DDS-score tekintetében azt tapasztaltuk, hogy az kifejezetten jól árnyalja az ECD-kritériumokat, és segítségével megmenthető a DDS C csoportba sorolással az eddig visszautasított donorvesék egy jelentős része. Természetesen ez is további vizsgálatokat igényel.

A KDRI/KDPI-vel kapcsolatban saját anyagunkban végzett vizsgálat alapján azt állapíthatjuk meg, hogy ezek, valamint a graftvesztés között korreláció van. A ROC-analízis alapján azonban nem lehetett számszerúsíteni egy olyan KDRI/KDPI értéket (úgynevezett „cut off point"-ot), amely prediktív lenne a graftvesztés előrejelzésében. Az alacsony mintaszámon túl a másik tényező, ami magyarázhatja a multivariancia-vizsgálat és ROC-analízis eredményét, hogy anyagunkban mind az elutasított, mind a transzplantációra alkalmasnak véleményezett donorok KDRI-értéke nagyon alacsony volt (2. táblázat), így a negatív predikció lehetősége szinte nem is kerülhetett be az analízisbe. Ennek hátterében donoraink relatíve alacsony életkora állhat, hiszen ez szerepel legnagyobb súllyal a KDRI számításában. Közlésekben a KDRI meghatározásakor maximális értékként 3,5-et állapítottak meg [6], saját beteganyagunkban még a beültetésre alkalmatlannak ítélt donorok átlagos KDRI-értéke is csak 1,44 volt (2. táblázat). Ez limitálhatja a ROC-analízis használhatóságát, ugyanakkor bátorít arra, hogy körültekintéssel ugyan, de merészebben fogadjunk el idősebb donorokból is vesét beültetésre. Egyúttal hosszabb távú utánkövetéses vizsgálat szükségességét is felveti, nagyobb beteganyagon és hosszabb utánkövetéssel, jelenlegi megállapításaink megerôsítéséhez.

Felmerül az a következtetés, hogy a betegeket az ECD-vel kapcsolatos eredményekról laikus számára érthető módon informálni kell, és ezzel kapcsolatosan döntési lehetőséget is biztosítani szükséges. Az ECD-alcsoportok és a rizikó mértékének számszerüsítése ezért is célunk, amelynek érdekében vizsgálatainkat folytatjuk.

Anyagi támogatás: A cikk megírása anyagi támogatásban nem részesült.

Szerzői munkamegosztás: Z. G., T. V., Zs. L., N. B.: A hipotézisek kidolgozása, a vizsgálat lefolytatása. Z. G., P. Sz. R., Zs. L., F. R., K. Zs., K. D. Á., A. L., N. B.: Donor- és recipiensmútét, a betegek posztoperatív gondozása. Z. G., T. V., P. Sz. R., Zs. L.: Adatgyưjtés. Z. G., T. V., F. R., N. B.: Statisztikai elemzés. Z. G., N. B.: A kézirat megszövegezése. A cikk végleges változatát valamennyi szerző elolvasta és jóváhagyta.

Érdekeltségek: A szerzőknek nincsenek érdekeltségeik.

\section{Köszönetnyilvánítás}

A szerzők köszönetet mondanak Cseke Barbarának, Illésy Lórántnak, Kabai Krisztinának, Szabó-Papp Marcellnak, Takács Tündének, Tóth Fruzsinának, valamint Záhonyi Anitának az adatgyújtésben nyújtott segítségükért.

\section{Irodalom}

[1] Meier-Kriesche, H. U., Kaplan, B.: Waiting time on dialysis as the strongest modifiable risk factor for renal transplant outcomes: a paired donor kidney analysis. Transplantation, 2002, 74(10), 1377-1381.

[2] Nemes, B., Gámán, G., Polak, W. G., et al.: Extended criteria donors in liver transplantation Part I: Reviewing the impact of determining factors. Expert Rev. Gastroenterol. Hepatol., 2016 Mar 3. [Epub ahead of print]

[3] Nemes, B., Gámán, G., Polak, W. G., et al.: Extended-criteria donors in liver transplantation Part II: Reviewing the impact of extended-criteria donors on the complications and outcomes of liver transplantation. Expert Rev. Gastroenterol. Hepatol., 2016 Mar 2. [Epub ahead of print]

[4] Port, F. K., Bragg-Gresham, J. L., Metzger, R. A., et al.: Donor characteristics associated with reduced graft survival: an approach to expanding the pool of kidney donors. Transplantation, 2002, 74(9), 1281-1286

[5] Nyberg, S. L., Matas, A. J., Kremers, W. K., et al.: Improved scoring system to assess adult donors for cadaver renal transplantation. Am. J. Transplant., 2003, 3(6), 715-721.

[6] Rao, P. S., Schaubel, D. E., Guidinger, M. K., et al.: A comprehensive risk quantification score for deceased donor kidneys: the kidney donor risk index. Transplantation, 2009, 88(2), 231-236.

[7] Zádori, G., Kovács, D. A., Fedor, R., et al.: Results of expandedcriteria donor kidneys: A single-center experience in Hungary. Transplant. Proc., 2015, 47(7), 2189-2191.

[8] Baskin-Bey, E. S., Kremers, W., Stegall, M. D., et al.: United Net work for Organ Sharing's expanded criteria donors: is stratification useful? Clin. Transplant., 2005, 19(3), 406-412.

[9] Professional Gudeline of NEFMI: Identification and classification of chronic kidney disease in adults based on the analysis of estimated GFR and proteinuria. [NEFMI Szakmai Kollégium. Egészségügyi szakmai irányelv - A felnőttkori idült vesebetegség felismerése és beosztása a számított GFR és a fehérjevizelés vizsgálatával.] 2014. http://nephrologia.hu/upload/nephrologia/ document/Az_idult_vesebetegseg_felismerese_es_beosztasa. pdf [Hungarian]

[10] Borda, B., Szederkényi, E., Ottlakán, A., et al.: Banff score chang es in kidneys from marginal donors. [Banff-score-változások a marginális donorokból származó veséknél.] Orv. Hetil., 2016, 157(8), 298-301. [Hungarian]

[11] De Fijter, J. W.: An old virtue to improve senior programs. Transplant. Int., 2009, 22(3), 259-268.

[12] Smits, J. M., Persijn, G. G., van Houwelingen, H. C., et al.: Evaluation of the Eurotransplant Senior Program. The results of the first year. Am. J. Transplant., 2002, 2(7), 664-670.

[13] Johnston, T. D., Thacker, L. R., Jeon, H., et al.: Sensitivity of expanded-criteria donor kidneys to cold ischaemia time. Clin. Transplant., 2004, 18(Suppl. 12), 28-32.

[14] Moreso, F., Serón, D., Gil-Vernet, S., et al.: Donor age and delayed graft function as predictors of renal allograft survival in rejectionfree patients. Nephrol. Dial. Transplant., 1999, 14(4), 930-935. 
[15] Cohen, B., Smits, J. M., Haase, B., et al.: Expanding the donor pool to increase renal transplantation. Nephrol. Dial. Transplant., 2005, 20(1), 34-41.

[16] Wolfe, R. A., Ashby, V. B., Milford, E. L., et al.: Comparison of mortality in all patients on dialysis, patients on dialysis awaiting transplantation, and recipients of a first cadaveric transplant. N. Engl. J. Med., 1999, 341(23), 1725-1730.

[17] Rao, P. S., Merion, R. M., Ashby, V. B., et al.: Renal transplantation in elderly patients older than 70 years of age: results from the Scientific Registry of Transplant Recipients. Transplantation, 2007, 83(8), 1069-1074.

[18] Büchler, M., Halimi, J. M., Najjar, A. A., et al.: Living with a functioning kidney transplant at 74 yr or older: a national epidemiological study. Clin. Transplant., 2004, 18(6), 681-685.

[19] Ojo, A. O., Hanson, J. A., Meier-Kriesche, H., et al.: Survival in recipients of marginal cadaveric donor kidneys compared with other recipients and wait-listed transplant candidates. J. Am. Soc. Nephrol., 2001, 12(3), 589-597.

[20] Waiser, J., Schreiber, M., Budde, K., et al.: Age-matching in renal transplantation. Nephrol. Dial. Transplant., 2000, 15(5), 696700 .

[21] Schold, J. D., Kaplan, B., Baliga, R. S., et al.: The broad spectrum of quality in deceased donor kidneys. Am. J. Transplant., 2005, 5(4), 757-765.

[22] Sung, R. S., Christensen, L. L., Leichtman, A. B., et al.: Determinants of discard of expanded criteria donor kidneys: impact of biopsy and machine perfusion. Am. J. Transplant., 2008, 8(4), 783-792.

[23] Cecka, J. M., Gritsch, H. A.: Why are nearly half of expanded criteria donor (ECD) kidneys not transplanted? Am. J. Transplant., 2008, 8(4), 735-736.

[24] Edwards, E. B., Posner, M. P., Maluf, D. G., et al.: Reasons for non-use of recovered kidneys: the effect of donor glomerulosclerosis and creatinine clearance on graft survival. Transplantation, 2004, 77(9), 1411-1415.
[25] Karpinski, J., Lajoie, G., Cattran, D., et al.: Outcome of kidney transplantation from high-risk donors is determined by both structure and function. Transplantation, 1999, 67(8), 11621167.

[26] Remuzzi, G., Cravedi, P., Perna, A., et al.: Long-term outcome of renal transplantation from older donors. N. Engl. J. Med., 2006, 354(4), 343-352.

[27] Anglicheau, D., Loupy, A., Lefaucheur, C., et al.: A simple clinicohistopathological composite scoring system is highly predictive of graft outcomes in marginal donors. Am. J. Transplant., 2008, $8(11), 2325-2334$

[28] Gandolfini, I., Buzio, C., Zanelli, P., et al.: The Kidney Donor Profile Index (KDPI) of marginal donors allocated by standardized pretransplant donor biopsy assessment: distribution and association with graft outcomes. Am. J. Transplant., 2014, 14(11), 2515-2525.

[29] Muruve, N. A., Steinbecker, K. M., Luger, A. M.: Are wedge biopsies of cadaveric kidneys obtained at procurement reliable? Transplantation, 2000, 69(11), 2384-2388.

[30] Remuzzi, G., Grinyò, J., Ruggenenti, P., et al.: Early experience with dual kidney transplantation in adults using expanded donor criteria. Double Kidney Transplant Group (DKG). J. Am. Soc. Nephrol., 1999, 10(12), 2591-2598.

[31] Randhawa, P.: Role of donor kidney biopsies in renal transplantation. Transplantation, 2001, 71(10), 1361-1365.

[32] Carter, J. T., Chan, S., Roberts, J. P., et al.: Expanded criteria donor kidney allocation: marked decrease in cold ischemia and delayed graft function at a single center. Am. J. Transplant., $2005,5(11), 2745-2753$.

(Zádori Gergely dr., Debrecen, Móricz Zsigmond krt. 22., 4032 e-mail: zadori.gergely@med.unideb.hu

\section{A rendezvények és kongresszusok híranyagának leadása}

a lap megjelenése előtt legalább 40 nappal lehetséges, a 6 hetes nyomdai átfutás miatt. Kérjük megrendelőink szíves megértését.

A híranyagokat a következő címre kérjük:

Orvosi Hetilap titkársága: Budai.Edit@akkrt.hu

Akadémiai Kiadó Zrt. 